\title{
EFFECT OF MgO ON CALCINATION AND PROPERTIES OF BELITE-BARIUM CALCIUM SULPHOALUMINATE CEMENT CLINKER WITH $\mathrm{Na}_{2} \mathrm{O}$ AND $\mathrm{K}_{2} \mathrm{O}$
}

\author{
WENYAN DAI*,**, ${ }^{\#}$ CHENCHEN GONG*,**, LINGCHAO LU*,**, XIN CHENG**** \\ *Shandong Provincial Key Laboratory of Preparation and Measurement of Building Materials \\ University of Jinan, Shandong 250022, China \\ **School of Material Science and Engineering, University of Jinan, Shandong 250022, China \\ \#E-mail: gongchenchenjinan@163.com
}

Submitted September 29, 2017; accepted January 2, 2018

\begin{abstract}
Keywords: $\mathrm{MgO}$, Belite-barium calcium sulphoaluminate cement, Properties, $\mathrm{R}_{2} \mathrm{O}$
The High-quality limestone resources decreased sharply worldwide, and MgO-rich limestone, as an important part of low-quality limestone, is widely used in the cement production because of its low cost. The purpose of this study was to explore the effect of $\mathrm{MgO}$ (1-9 wt. \%) on the composition and properties of belite-barium calcium sulphoaluminate cement with $\mathrm{Na}_{2} \mathrm{O}$ and $\mathrm{K}_{2} \mathrm{O}$. The experimental results showed that $1 \sim 3 \mathrm{wt} \%$ of $\mathrm{MgO}$ in the mineral composition was in favor of calcining and stabilizing the crystal structure of $M_{3}-C_{3} S, R-C_{3} S$ and $\beta-C_{2} S$ in the cement clinker. Furthermore, the addition of $\mathrm{MgO}$ evidently increased the content of $R-C_{3} S$ and $\beta-C_{2} S$ and goes up to the highest value of $14.47 \%$ and $22.4 \%$ when the addition of $\mathrm{MgO}$ reaches $7 \mathrm{wt} . \%$, and the increment of $R-C_{3} S$ and $\beta-C_{2} S$ was beneficial to improve the mechanical strength of the clinker. The $3 d, 7 d$ and $28 d$ compressive strength of the cement with $7 \mathrm{wt} . \% \mathrm{MgO}$ increased by about $26 \%, 7.3 \%$ and $36.2 \%$ than that without $\mathrm{MgO}$. Meanwhile, since the addition of $\mathrm{MgO}$ also can promote the formation of C4AF, but has little effect on the formation of $C_{2.75} B_{1.25} A_{3} \bar{S}$ and $C_{3} A$, the $C_{3} A / C_{4} A F$ ratio present significantly reduction, which indicate that $M g O$ can reduce the viscosity of the liquid phase in the process of calcination. So, the utilization of $\mathrm{MgO}$ in low-quality limestone has a great potential to develop low-carbon and sustainable society in producing the belite-barium calcium sulphoaluminate cement.
\end{abstract}

\section{INTRODUCTION}

With the progress and development of society, green, low-carbon and sustainable development were increasingly focused. Manufacturing of Portland cement not only consume a large quantity of raw materials and energy, but also has a considerable negative environmental impact, so cement industry had always been criticized [1, 2]. For example, the manufacture of Portland cement as the most widely used building materials took about 1.7 tons of raw materials (limestone, clay, etc.) and $8.5 \times 10^{5} \mathrm{kcal}$ of energy to produce 1 ton of cement clinker. Meanwhile, 0.97 tons of $\mathrm{CO}_{2}$ on average were emitted with per ton of cement produced [3-7]. It was the development direction of cement industry to reduce energy consumption, environmental pollution and improve performances of cement [4-6]. Under these circumstances belite-barium calcium sulphoaluminate cement $\left(\mathrm{C}_{2.75} \mathrm{~B}_{1.25} \mathrm{~A}_{3} \$\right)$ was prepared. It had low synthesis temperature, low limestone consumption, low $\mathrm{CO}_{2}$ emissions (less than $10 \%$ of Portland cement), low hydration heat and good durability [4, 8-10].

In recent years, sustainable development and natural resources preservation have become global concerns. High-quality limestone resources are becoming increasingly rare, and it is deduced that 29 billion tons will be consumed in the next 20 years $[11,12]$. Thus, the utilization of low-grade limestone has gained more and more attention, and $\mathrm{MgO}$-rich limestone is one of them. It is well known to us that $\mathrm{MgO}$-rich limestone is abundant in China, but this kind of limestone' usage in Portland cement production is rare [13]. In the process of manufacture of belite-barium calcium sulphoaluminate cement, low-grade raw material was used which inevitably introduced impurity ions to affect the production and performance of cement. However it had been reported that for Portland cement $\mathrm{MgO}$ could lower the melting temperature, increase the quantity of the liquid phase, change the mineral phases' crystal structure and activate the reactivity of $\mathrm{C}_{3} \mathrm{~S}[14,16]$. The study of S.S. Rehsi observed that doping $\mathrm{MgO}$ in cement could extend the hydration of cement and Ángeles G.De la Torre et al. found the addition of $\mathrm{MgO}$ changes the crystal structure of minerals in the clinker $[17,18]$.

Besides, $\mathrm{Na}_{2} \mathrm{O}$ and $\mathrm{K}_{2} \mathrm{O}$ (alkali) were the most frequently existing minor components in the natural raw materials and had been reported to stabilize $\alpha^{\prime} \mathrm{H}-\mathrm{C}_{2} \mathrm{~S}$ and $\alpha-\mathrm{C}_{2} \mathrm{~S}$ in belite clinkers [5, 19]. Considering the advantages of $\mathrm{MgO}, \mathrm{Na}_{2} \mathrm{O}$ and $\mathrm{K}_{2} \mathrm{O}$ to manufacture of Portland cement, they were expected to affect belite-barium calcium sulphoaluminate cement with the same method and mechanism. However, to the current authors' knowledge no such work has been reported. 
In this paper the effect of $\mathrm{MgO}$ was investigated in the mineral formation of belite-barium calcium sulphoaluminate cement clinker in the presence of $\mathrm{Na}_{2} \mathrm{O}$ and $-\mathrm{K}_{2} \mathrm{O}$. Meanwhile hydration and hardening properties, such as compressive strength development, hydration rate, hydration heat release and microstructures of hydration products, were characterized. It was hoped that this paper could offer available data for further industrial production of belite-barium calcium sulphoaluminate cement and effective utilization of magnesia-rich limestone in this type of cement clinker.

\section{EXPERIMENTAL}

\section{Sample preparation}

The cement clinker was synthesized using analytical reagent grades of $\mathrm{CaCO}_{3}, \mathrm{SiO}_{2}(99.0 \%$ from Damao Chemical Reagent Factory, China), $\mathrm{Fe}_{2} \mathrm{O}_{3}, \mathrm{Al}_{2} \mathrm{O}_{3}$, $\mathrm{BaSO}_{4}, \mathrm{BaCO}_{3}, \mathrm{CaF}_{2}, \mathrm{MgO}, \mathrm{Na}_{2} \mathrm{CO}_{3}$ and $\mathrm{K}_{2} \mathrm{CO}_{3}(99.0 \%$ from Sinopharm Chemical Reagent Co., Ltd, China), to eliminate the influences of other impurities on cement clinker production as much as possible. The designed mineral composition and chemical composition of belite-barium calcium sulphoaluminate cement clinker were listed in Table 1(the blank clinker without dopants), and $0.6 \% \mathrm{CaF}_{2}$ was added as the mineralizing agent.

In the reference sample, the content of $\mathrm{Na}_{2} \mathrm{O}$ and $\mathrm{K}_{2} \mathrm{O}$ was 0.5 wt. $\%$ and 1.2 wt. $\%\left(\mathrm{Na}_{2} \mathrm{O} \cdot \mathrm{eq}=1.29\right.$; percentage in relation to the blank clinker, the same rule applies as follows) respectively, which were added into the raw materials of the blank clinker. Then six samples are prepared by adding $0,1,3,5,7$ and 9 wt. $\% \mathrm{MgO}$ into the reference sample, and they are named as $\mathrm{C} 0, \mathrm{C} 1, \mathrm{C} 3$, C5, C7 and C9, respectively.

Raw materials (with particle sizes finer than 74 $\mu \mathrm{m})$ were mixed and wet ground in a planetary mill for 40 minutes to ensure a homogenous mixture resulted in. Mixtures were then dried to a water content of about $10 \%$ by weight and compressed to form $\Phi 60 \mathrm{~mm} \times 10 \mathrm{~mm}$ cylindrical specimens. The cylinders were oven-dried at $105^{\circ} \mathrm{C}$ for $1-2 \mathrm{~h}$ before being calcined at a heating rate of $5^{\circ} \mathrm{C} \cdot \mathrm{min}^{-1}$ to $1380^{\circ} \mathrm{C}$ and held for $90 \mathrm{~min}$ and then cooled down quickly. The calcined samples were ground to the residue weight of a $74 \mu \mathrm{m}$ sieve less than $5 \%$ by a planetary mill prior to property measurements.

The ground clinkers were mixed with $10.0 \mathrm{wt}$. \% $\mathrm{CaSO}_{4} \cdot 2 \mathrm{H}_{2} \mathrm{O}$ (99.0\% from Sinopharm Chemical Reagent Co., Ltd, China). Then, cement pastes were prepared at a water/cement ratio of 0.30 , cast in $20 \mathrm{~mm} \times 20 \mathrm{~mm} \times 20 \mathrm{~mm}$ molds, vibrated to remove air bubbles, and then wiped to achieve surface flat with a scraper. The molded pastes were kept at $20 \pm 2^{\circ} \mathrm{C}$ and relative humidity exceeding $95 \%$ for $24 \mathrm{~h}$, and then removed from the molds. The demolded pastes were then cured in a water tank at $20 \pm 2{ }^{\circ} \mathrm{C}$ for 3,7 and 28 days.

\section{Test method \\ $f$-CaO tests}

The content of $\mathrm{f}-\mathrm{CaO}$ in cement clinkers was measured by ethanediol-alcohol method according to GB/T 176-2008 Methods for Chemical Analysis of Cement.

\section{$X$-ray diffraction $(X R D)$}

XRD data were collected on D8 ADVANCE X-ray diffractometer with strictly monochromatic $\mathrm{Cu} \mathrm{K} \alpha$ radiation $(\lambda=0.154 \mathrm{~nm})$ produced by Bruker in Germany. The overall measurements for clinkers were carried out in the range of $10^{\circ}$ to $60^{\circ}(2 \theta)$ with a step size of $0.02^{\circ}(2 \theta)$, a step time of $4 \mathrm{~s}$ per pattern, an accelerating voltage of $40 \mathrm{kV}$ and a current of $40 \mathrm{~mA}$. Besides, the measurements for hydration products were carried out in the range of $5^{\circ}$ to $60^{\circ}(2 \theta)$ with a step size of $0.02^{\circ}(2 \theta)$, a step time of $0.2 \mathrm{~s}$ per pattern.

To quantitatively evaluate the amount of crystalline phases in the samples, Quantitative XRD (Q-XRD) technique was used during this work. Q-XRD results were obtained through the Rietveld method [20,21]. For this purpose, all samples were characterized by Laboratory X-ray powder diffraction (LXPRD). LXPRD plots were analyzed using the Rietveld method with Topas 4.2 software package from Bruker AXS GmbH [22, 23].

\section{Petrographic description}

Microscopic images of clinkers were captured by using a Motic 310A microscope (Motic Instruments Inc., Canada) equipped with a Moticam Pro 285A camera. The samples were embedded in the sublimed sulfur before polishing. The polishing process was performed on the glass by hand with three kinds of fineness of aluminium oxide, and the polished samples were cleaned in absolute ethyl alcohol with an ultrasonic cleaner for 10 minutes. The polished surface was etched in $1 \%$ ammonium chloride aqueous solution for 6 seconds.

\section{Scanning electron microscopy} (SEM)

Pieces of hydrated samples at different ages were coated with carbon to provide a conductive surface for SEM imaging. Observation of mineral morphological

Table 1. Designed mineral composition (wt. \%) and chemical composition of raw materials (expressed as oxides, wt. \%).

\begin{tabular}{|c|c|c|c|c|c|c|c|c|c|c|}
\hline $\mathrm{C}_{3} \mathrm{~S}$ & $\mathrm{C}_{2} \mathrm{~S}$ & $\mathrm{C}_{3} \mathrm{~A}$ & $\mathrm{C}_{4} \mathrm{AF}$ & $\mathrm{C}_{2.75} \mathrm{~B}_{1.25} \mathrm{~A}_{3} \overline{\mathrm{S}}$ & $\mathrm{SiO}_{2}$ & $\mathrm{Al}_{2} \mathrm{O}_{3}$ & $\mathrm{Fe}_{2} \mathrm{O}_{3}$ & $\mathrm{CaO}$ & $\mathrm{SO}_{3}$ & $\overline{\mathrm{BaO}}$ \\
\hline 37.5 & 37.5 & 4.6 & 11.5 & 9.0 & 22.4 & 7.7 & 3.7 & 60.6 & 1.4 & 4.1 \\
\hline
\end{tabular}


feature was examined by using a Field Emission Scanning Electron Microscope (GUANTA 250-FEG,USA) with a Link Energy Disperse Spectroscopy (LinkISIS300 type, UK) system. The distribution of elements in minerals was analyzed by Energy Spectrum analysis (EDS).

\section{Compressive strength}

Compressive strength of the samples at 1, 3, 7 and 28 days was evaluated by a universal compression machine (MTS CMT5504, USA). Each representative value was an average determined from six specimens with same formulation and curing condition.

\section{Hydration heat-evolution test}

An isothermal heat-conduction calorimetry (TAM air C80, Thermometric, Sweden) was used to measure the hydration heat evolution of cements with $10.0 \mathrm{wt}$. \% $\mathrm{CaSO}_{4} \cdot 2 \mathrm{H}_{2} \mathrm{O}$. The water/cement ratio was 0.45 and experimental temperature was $30.0 \pm 0.1^{\circ} \mathrm{C}$. Cements and water were tempered for several hours before mixing, then water was injected into the reaction vessel and the samples were stirred in the calorimeter for several minutes. This procedure allowed monitoring the heat evolution from the very beginning when water was added. Data acquisition was performed for about 6 days.

\section{RESULTS AND DISCUSSION}

\section{f- $\mathrm{CaO}$ content}

The variations of $\mathrm{f}-\mathrm{CaO}$ content in clinker samples with the addition of $\mathrm{MgO}$ are given in Figure 1. It can be seen from Figure 1, the content of $\mathrm{f}-\mathrm{CaO}$ in all cement clinker samples was less than $0.80 \%$. This is a good indicator of the burnability of raw materials. In reference sample, the content of $\mathrm{f}-\mathrm{CaO}$ was $0.46 \%$. With the rises of $\mathrm{MgO}$ dosage, the $\mathrm{f}-\mathrm{CaO}$ content in cement clinkers decreased firstly and then increased, but the volatility was not obvious. When $\mathrm{MgO}$ dosage was $1.0 \sim 3.0$ wt. \%, the content of $\mathrm{f}-\mathrm{CaO}$ decreased obviously and when

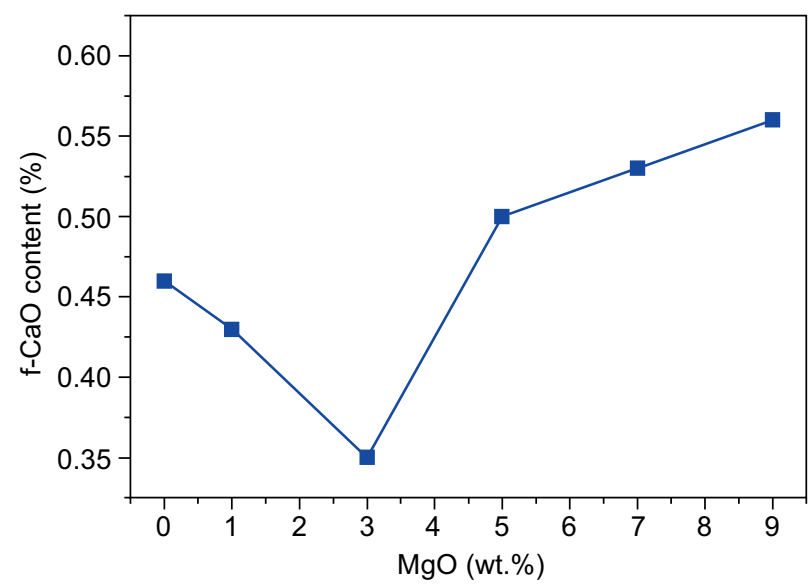

Figure 1. f-CaO content of clinker samples.
$\mathrm{MgO}$ dosage was 3.0 wt. \%, $\mathrm{f}-\mathrm{CaO}$ content reached the lowest, only $0.35 \%$. This is attributed to good fluxing effect of $\mathrm{MgO}$, because a suitable amount of $\mathrm{MgO}$ can reduce the viscosity of the liquid phase and increase the content of liquid phase to promote the formation of $\mathrm{C}_{3} \mathrm{~S}$, during which $\mathrm{f}-\mathrm{CaO}$ was consumed $[24,25]$. However, when $\mathrm{MgO}$ dosage was over 3.0 wt. $\%$, the $\mathrm{f}-\mathrm{CaO}$ content increased remarkably and $\mathrm{MgO}$ dosage reach to $9.0 \mathrm{wt}$. \%, the content of $\mathrm{f}-\mathrm{CaO}$ is 0.56 . So it was concluded that a high $\mathrm{MgO}$ content (>3.0 wt. \%) is not helpful for the burnability.

\section{XRD analysis of hydration products}

XRD patterns of all studied clinkers are showed in Figure 2. The quantitative phase analysis of clinker minerals in different polymorphs will be discussed below. It can be seen from Figure 2 that characteristic mineral $\mathrm{C}_{275} \mathrm{~B}_{1.25} \mathrm{~A}_{3} \$$ and the main minerals of Portland cement are seen in this new type of cement clinker. The characteristic diffraction peaks of $\mathrm{C}_{2.75} \mathrm{~B}_{1.25} \mathrm{~A}_{3} \$$ had slightly enhanced in $\mathrm{C} 3 \sim \mathrm{C} 7$ samples, indicating $3.0 \sim 7.0$ wt. $\%$ content of $\mathrm{MgO}$ contributed to the formation of $\mathrm{C}_{2.75} \mathrm{~B}_{1.25} \mathrm{~A}_{3} \$$. In addition, with the increase

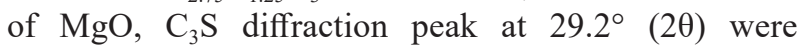
significantly enhanced in $\mathrm{C} 3, \mathrm{C} 7$ and $\mathrm{C} 9$ samples, and the other diffraction peak about $\mathrm{C}_{3} \mathrm{~S}$ and $\mathrm{C}_{2} \mathrm{~S}$ changed not obvious. What's more, after doping $\mathrm{MgO}$, diffraction peaks of $\mathrm{C}_{4} \mathrm{AF}\left(2 \theta=12.1^{\circ}\right)$ significantly enhanced, while the diffraction peaks of $\mathrm{C}_{3} \mathrm{~A}$ had little changed. This variation suggests that $\mathrm{MgO}$ promotes the formation of $\mathrm{C}_{4} \mathrm{AF}$, which is consistent with Li's findings, but affects little on the formation of $\mathrm{C}_{3} \mathrm{~A}[13,26]$. Besides, when $\mathrm{MgO}$ content was 5.0 wt. \%, the diffraction peak of $\mathrm{f}-\mathrm{MgO}$ appeared and its intensity increased with the $\mathrm{MgO}$ content increasing, which indicated that excessed $\mathrm{MgO}$ in the clinker will result in $\mathrm{f}-\mathrm{MgO}$.

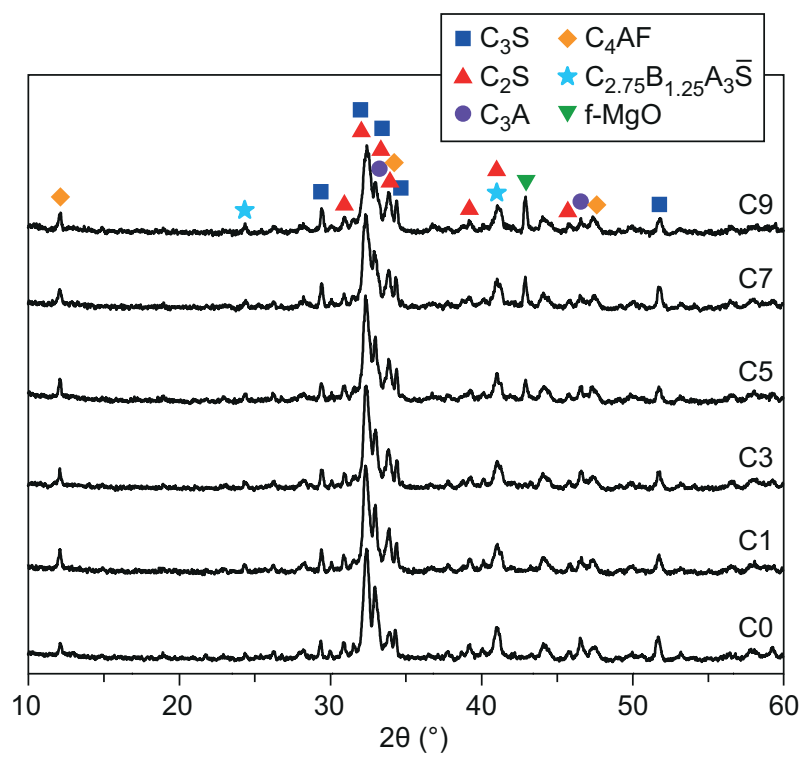

Figure 2. XRD patterns of cement clinkers doped with $\mathrm{MgO}$. 
Rietveld quantitative phase analysis

There are various crystalline phases in belitebarium calcium sulphoaluminate cement clinker, and some crystalline phase displayed polymorphism. In the Q-XRD analysis, the $\mathrm{C}_{2.75} \mathrm{~B}_{1.25} \mathrm{~A}_{3} \$$ mineral was not taken into account, because the crystal structure data for Rietveld quantitative analysis had not been established, and the doping elements had little effect on its formation. Table 2 showed the quantitative phase analysis results for all clinkers, as well as the Rietveld agreement factor for the refinements. It was observed that, parameters Rwp were lower than 15 , it means the high credibility of refinement $[21,27]$. The content of $\mathrm{C}_{3} \mathrm{~S}$ was $37.57 \%$ in $\mathrm{C} 0$ sample and it was lower than that of in $\mathrm{C} 3, \mathrm{C} 7$ and $\mathrm{C} 9$ samples. With the increase of $\mathrm{MgO}$ dosage, $\mathrm{C}_{2} \mathrm{~S}$ contents on a corresponding reduction. This indicated that high doped $\mathrm{MgO}$ facilitated the formation of $\mathrm{C}_{3} \mathrm{~S}$. This may be because in belite-barium calcium sulphoaluminate cement, when $\mathrm{MgO}$ dosage exceeded 5.0 wt. \%, the quantity of $\mathrm{Mg}^{2+}$ sufficient to formed $\left[\mathrm{MgO}_{6}\right]^{10-}$.It had a big different with $\left[\mathrm{SiO}_{4}\right]^{4-}$ in structure, shape and size, thus causing the phase interfacial energy increased, and providing favorable conditions for the formation of $\mathrm{C}_{3} \mathrm{~S}$ minerals. From Figure 3, we also observed that f-MgO generated when $\mathrm{MgO}$ dosage exceeded 5 wt. \%, corresponding to the results shown in Figure 2.

Table 2. Rietveld quantitative phase analysis results of mineral composition of the resultant clinkers (wt. \%).

\begin{tabular}{lccccrr}
\hline Code & $\mathrm{C} 0$ & $\mathrm{C} 1$ & $\mathrm{C} 3$ & $\mathrm{C} 5$ & $\mathrm{C} 7$ & $\mathrm{C} 9$ \\
\hline $\mathrm{M}_{3}-\mathrm{C}_{3} \mathrm{~S}$ & 33.39 & 21.66 & 21.4 & 27.71 & 21.18 & 24.61 \\
$\mathrm{~T}_{3}-\mathrm{C}_{3} \mathrm{~S}$ & 4.18 & 6.02 & 3.97 & 1.67 & 3.14 & 2.75 \\
$\mathrm{R}^{-} \mathrm{C}_{3} \mathrm{~S}$ & 0 & 10.02 & 13.23 & 7.72 & 14.47 & 10.81 \\
Total- $_{3} \mathrm{~S}$ & 37.57 & 37.7 & 38.6 & 37.1 & 38.79 & 38.17 \\
$\alpha^{\prime} \mathrm{L}-\mathrm{C}_{2} \mathrm{~S}$ & 34.31 & 26.77 & 20.62 & 21.75 & 16.06 & 18.38 \\
$\beta-\mathrm{C}_{2} \mathrm{~S}$ & 8.85 & 15.46 & 20.93 & 21.75 & 22.03 & 20.02 \\
Total- $\mathrm{C}_{2} \mathrm{~S}$ & 43.16 & 42.23 & 41.55 & 42.45 & 38.09 & 38.40 \\
$\mathrm{C}_{3} \mathrm{~A}$ & 8.18 & 8.44 & 8.28 & 7.78 & 8.08 & 7.33 \\
$\mathrm{C}_{4} \mathrm{AF}$ & 10.65 & 11.22 & 11.24 & 10.34 & 10.8 & 10.01 \\
$\mathrm{f}-\mathrm{CaO}$ & 0.44 & 0.41 & 0.33 & 0.49 & 0.55 & 0.58 \\
$\mathrm{f}-\mathrm{MgO}$ & 0 & 0 & 0 & 1.84 & 3.69 & 5.51 \\
$\mathrm{Rwp}$ & 14.37 & 12.59 & 10.71 & 11.87 & 11.45 & 9.70 \\
\hline
\end{tabular}

* Rwp is the agreement factor of the Rietveld refinement

\section{Silicate phases}

Figure 3 showed the relative content of high temperature polymorphs $\left(\mathrm{M}_{3} \mathrm{~T}_{3}\right.$ and $\left.\mathrm{R}\right)$ of $\mathrm{C}_{3} \mathrm{~S}$, which was calculated from quantitative phase analysis. It was reported that $\mathrm{M}_{3}-\mathrm{C}_{3} \mathrm{~S}$ and $\mathrm{R}-\mathrm{C}_{3} \mathrm{~S}$ have better hydration activity than $\mathrm{T}_{3}-\mathrm{C}_{3} \mathrm{~S}$ [28]. From Figure 3, we can see that none $\mathrm{MgO}$-doped sample was primarily $\mathrm{M}_{3}-\mathrm{C}_{3} \mathrm{~S}$, indicating that the incorporation of $\mathrm{Na}_{2} \mathrm{O}$ and $\mathrm{K}_{2} \mathrm{O}$ can stabilize the high temperature crystalline $\mathrm{M}_{3}-\mathrm{C}_{3} \mathrm{~S}$ at room temperature. When doped $\mathrm{MgO}, \mathrm{R}-\mathrm{C}_{3} \mathrm{~S}$ appeared in clinker, meanwhile $\mathrm{T}_{3}-\mathrm{C}_{3} \mathrm{~S}$ had decreased, which may contribute to the increase of the compressive strength and it can indicate that a certain amount of alkali-doped, $\mathrm{MgO}$ can stabilize a portion of $\mathrm{R}-\mathrm{C}_{3} \mathrm{~S}$. In the samples of 3.0 wt. $\% \mathrm{MgO}$ and 7.0 wt. $\% \mathrm{MgO}$ content, $\mathrm{R}-\mathrm{C}_{3} \mathrm{~S}$ content was relatively high, respectively $13.23 \%$ and $14.47 \%$. When $\mathrm{MgO}$ dosage was 5.0 wt. \%, R-C $\mathrm{C}_{3} \mathrm{~S}$ content decreased, but $\mathrm{M}_{3}-\mathrm{C}_{3} \mathrm{~S}$ content increased. So it can be concluded that $\mathrm{MgO}$ favors the formation of $\mathrm{C}_{3} \mathrm{~S}$ and the stabilization of $\mathrm{M}_{3}-\mathrm{C}_{3} \mathrm{~S}$ and $\mathrm{R}-\mathrm{C}_{3} \mathrm{~S}$, in which the effect was more obvious in 3.0 wt. $\% \mathrm{MgO}$ and $7.0 \mathrm{wt}$. \% $\mathrm{MgO}$ content.

The content of belite phase crystallized in different polymorphs present in clinkers co-doped with $\mathrm{MgO}$ calculated from quantitative phase analysis is illustrated in Figure 4. It has been reported that the order of hydration degree for different types of $\mathrm{C}_{2} \mathrm{~S}$ was $\alpha-\mathrm{C}_{2} \mathrm{~S}$ $>\alpha_{\mathrm{H}}^{\prime}-\mathrm{C}_{2} \mathrm{~S}>\beta-\mathrm{C}_{2} \mathrm{~S}>\alpha_{\mathrm{L}}^{\prime}-\mathrm{C}_{2} \mathrm{~S}>\gamma-\mathrm{C}_{2} \mathrm{~S}$ during the same curing period and condition, and $\gamma-\mathrm{C}_{2} \mathrm{~S}$ scarcely reacted with water at ambient temperature [29-31], so $\gamma-C_{2} S$ was not the desirable polymorph. In the present study, it can

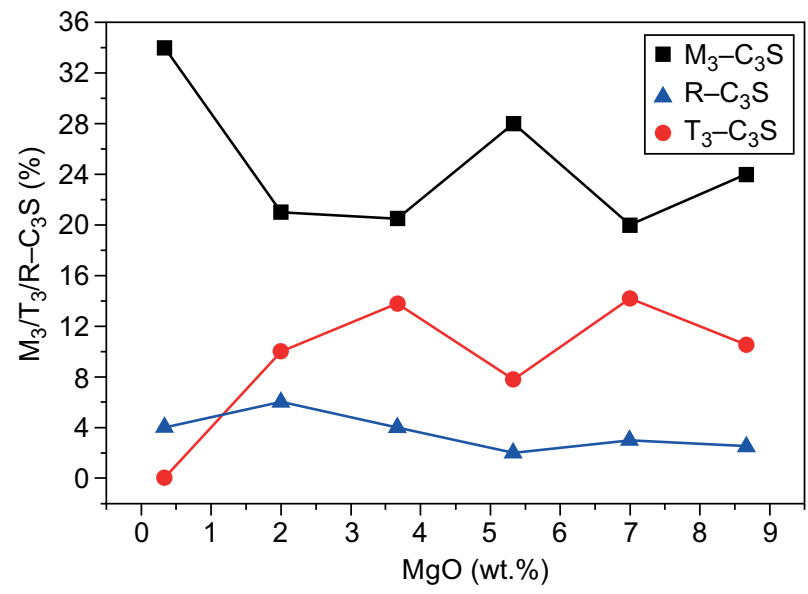

Figure 3. Relative content of $\mathrm{M}_{3}-\mathrm{C}_{3} \mathrm{~S} \mathrm{~T}_{3}-\mathrm{C}_{3} \mathrm{~S}$ and $\mathrm{R}-\mathrm{C}_{3} \mathrm{~S}$ in samples.

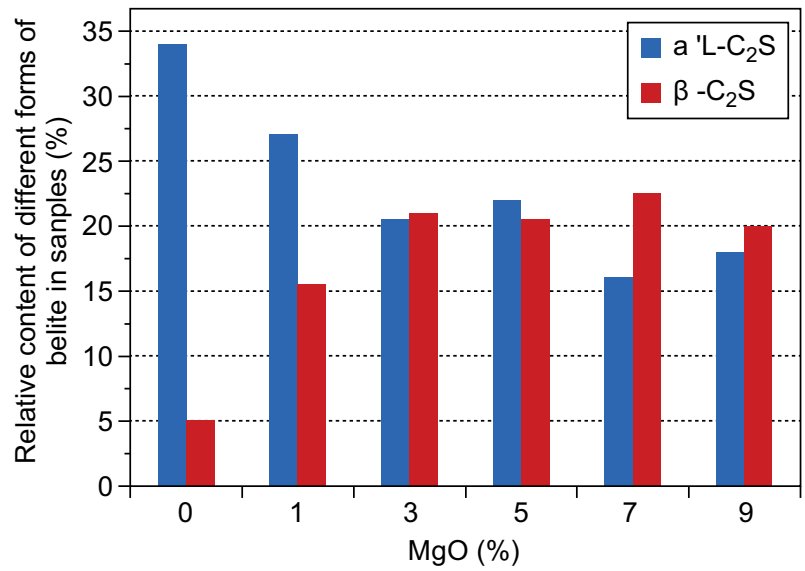

Figure 4. Content of different polyforms of belite in cement clinkers. 
be seen from Figure 4 that different amount of $\beta-\mathrm{C}_{2} \mathrm{~S}$ and $\alpha_{\mathrm{L}}^{\prime}-\mathrm{C}_{2} \mathrm{~S}$ exist and no $\gamma-\mathrm{C}_{2} \mathrm{~S}$ was found. In addition, Figure 4 also showed that with the dosage of $\mathrm{MgO}$ changed, different polymorphs of $\mathrm{C}_{2} \mathrm{~S}$ will also change in cement clinker and mainly had $\alpha^{\prime} \mathrm{L}-\mathrm{C}_{2} \mathrm{~S}$, reached to $34.31 \%$. After doping $\mathrm{MgO}, \beta-\mathrm{C}_{2} \mathrm{~S}$ increased significantly in samples, indicating that $\mathrm{MgO}$ can stabilize $\beta-\mathrm{C}_{2} \mathrm{~S}$. When $\mathrm{MgO}$ dosage was 7.0 wt. $\%, \beta-\mathrm{C}_{2} \mathrm{~S}$ content was relatively high in samples. Due to the hydration performance of $\beta-C_{2} S$ better than $\alpha^{\prime} L-C_{2} S$, therefore, more $\beta-C_{2} S$ content promoted cement hydration.

\section{Interstitial phases}

In belite-barium calcium sulphoaluminate cement clinker, $\mathrm{C}_{3} \mathrm{~A}$, and $\mathrm{C}_{4} \mathrm{AF}$ all belong to the interstitial phases [20]. According to the results of Figure 2, $\mathrm{C}_{3} \mathrm{~A}$ and $\mathrm{C}_{4} \mathrm{AF}$ are further studied here. It has been reported that $\mathrm{MgO}$ dominates the $\mathrm{C}_{3} \mathrm{~A}$ formation and the increase of $\mathrm{MgO}$ can decrease the amount of $\mathrm{C}_{3} \mathrm{~A}$ in Portland cement [24], however this rule was not observed in this study and the formation of $\mathrm{C}_{3} \mathrm{~A}$ is not regular with different doping amounts of $\mathrm{MgO}$ (Table 2). It has to be highlighted that the liquid viscosity is significantly influenced by the dopants. The liquid viscosity was characterized by the $\mathrm{C}_{3} \mathrm{~A} / \mathrm{C}_{4} \mathrm{AF}$ ratio of the clinkers. The results were illustrated in Figure 5. $\mathrm{C}_{3} \mathrm{~A} / \mathrm{C}_{4} \mathrm{AF}$ ratio showed a tendency of decrease and then increase in the clinker samples along with $\mathrm{MgO}$ dosage increasing. It also had been said, $\mathrm{MgO}$ was possible to reduce the viscosity of the liquid. In addition, it can be seen that when doped with 3.0 wt. $\% \mathrm{MgO}, \mathrm{C}_{3} \mathrm{~A} / \mathrm{C}_{4} \mathrm{AF}$ significantly reduced, and then with $\mathrm{MgO}$ content was higher than $3.0 \mathrm{wt}$. $\%$, the $\mathrm{C}_{3} \mathrm{~A} / \mathrm{C}_{4} \mathrm{AF}$ was increased firstly then decreased, but overall a very small fluctuation range. $\mathrm{C}_{3} \mathrm{~A} / \mathrm{C}_{4} \mathrm{AF}$ maximum ratio (5.0 wt. \% $\mathrm{MgO}$ ) and $\mathrm{C}_{3} \mathrm{~A} / \mathrm{C}_{4} \mathrm{AF}$ minimum ratio $(9.0 \mathrm{wt} . \% \mathrm{MgO})$ only a difference of 0.018 , it was little difference on $\mathrm{C}_{3} \mathrm{~A} / \mathrm{C}_{4} \mathrm{AF}$ in 3.0 wt. $\% \sim 9.0$ wt. $\% \mathrm{MgO}$ samples. Overall, high-

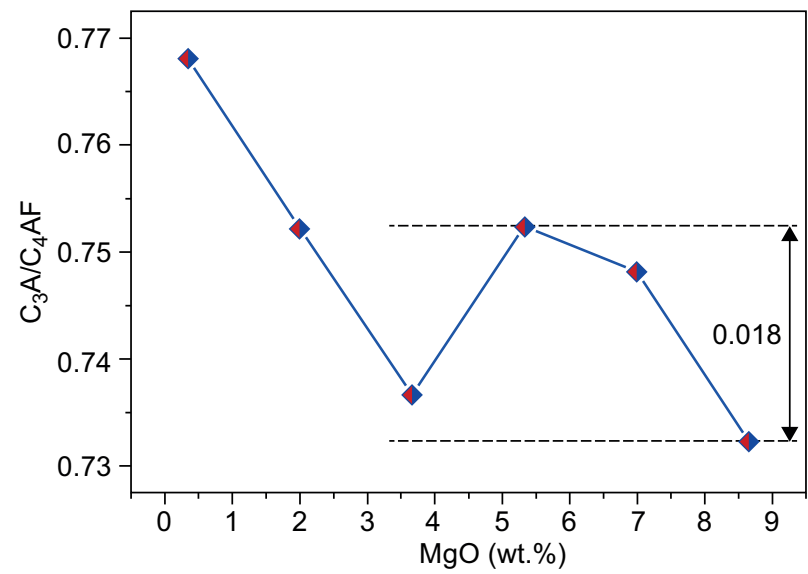

Figure 5. The variation curve of $\mathrm{C} 3 \mathrm{~A} / \mathrm{C} 4 \mathrm{AF}$ ratio of the resultant clinkers. doped $\mathrm{MgO}$ can reduce $\mathrm{C}_{3} \mathrm{~A} / \mathrm{C}_{4} \mathrm{AF}$ ratio and reduce the viscosity of the liquid phase, which will be benefit to $\mathrm{f}-\mathrm{CaO}$ absorb and promote the formation of $\mathrm{C}_{3} \mathrm{~S}$ clinker. The results were in accordance with the results of Figure 1 .

\section{Microscopic observation}

The microscopic images of clinkers captured by metallurgical microscope were presented in Figure 6. It was known that in cement clinker alite occurred as angular subhedral to euhedral crystals in blue color, whereas belite occurred as round and lamellar crystals in tan-to-brown color [26, 32]. In C0 sample, the size of alite was $5 \sim 40 \mu \mathrm{m}$ which was hexagonal plate-like and columnar, and the size of belite was $7 \sim 40 \mu \mathrm{m}$ which was round granular. Alite and belite distribution was uniform, and the boundary of crystal was clear, which indicating high doped alkali was beneficial to mineral development. Comparing with $\mathrm{C} 3$ and $\mathrm{C} 0$ petrographic photos, the size of alite slightly reduced and the number increased in $\mathrm{C} 3$, while the size of belite changed little. Comparing with

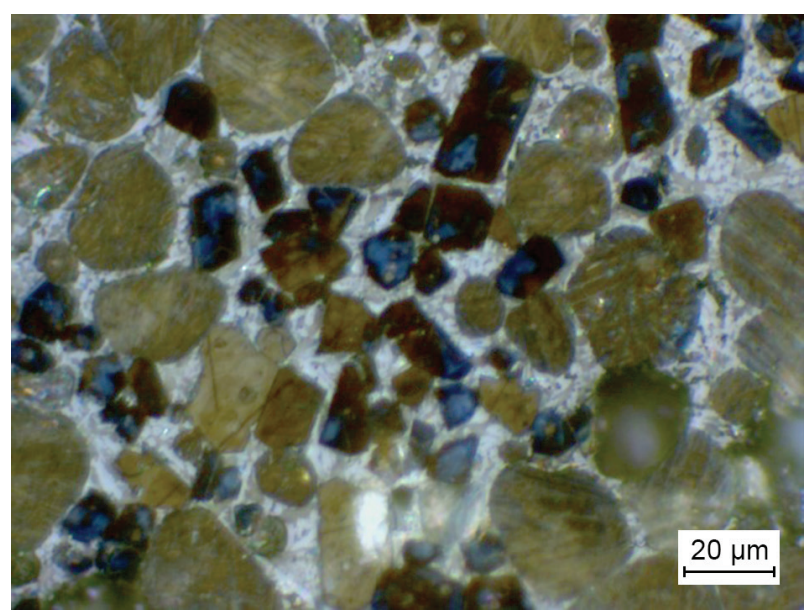

a) $\mathrm{C} 0$

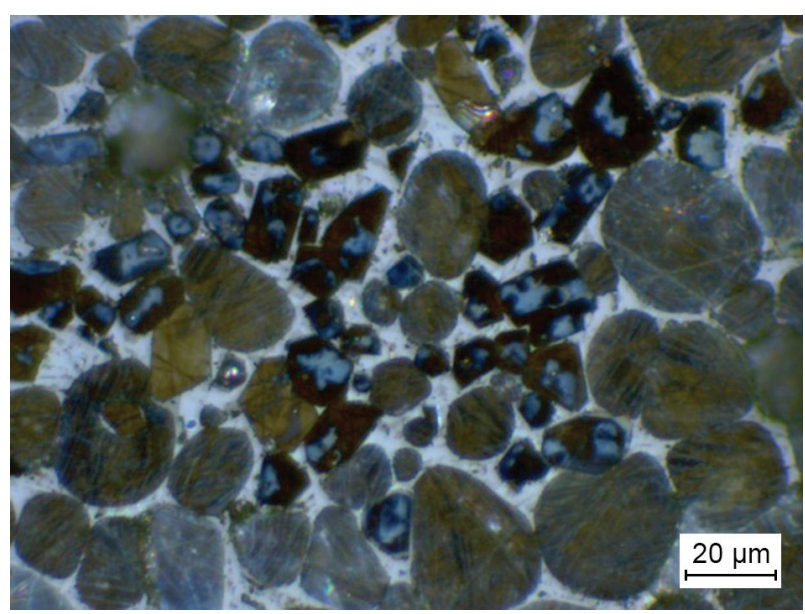

b) $\mathrm{C} 3$

Figure 6. Microscopic view of clinker samples. (Continue on next page) 


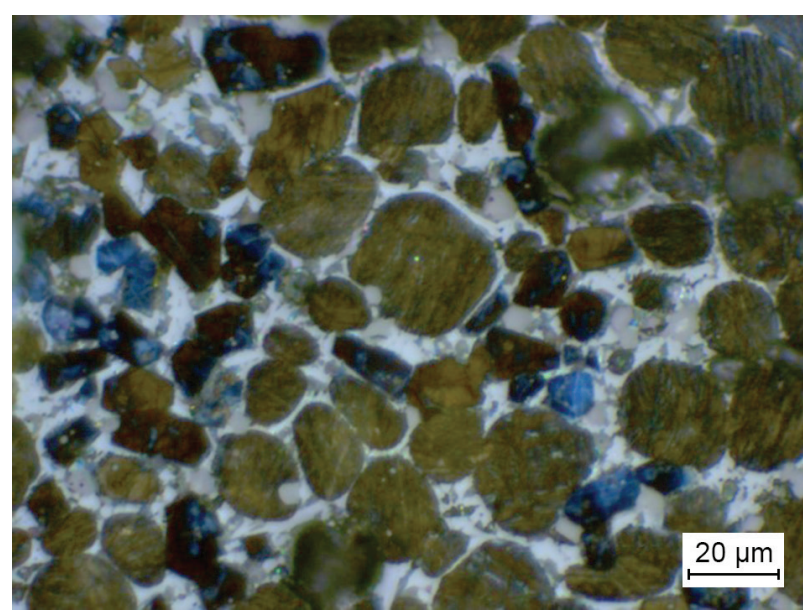

c) $\mathrm{C} 5$

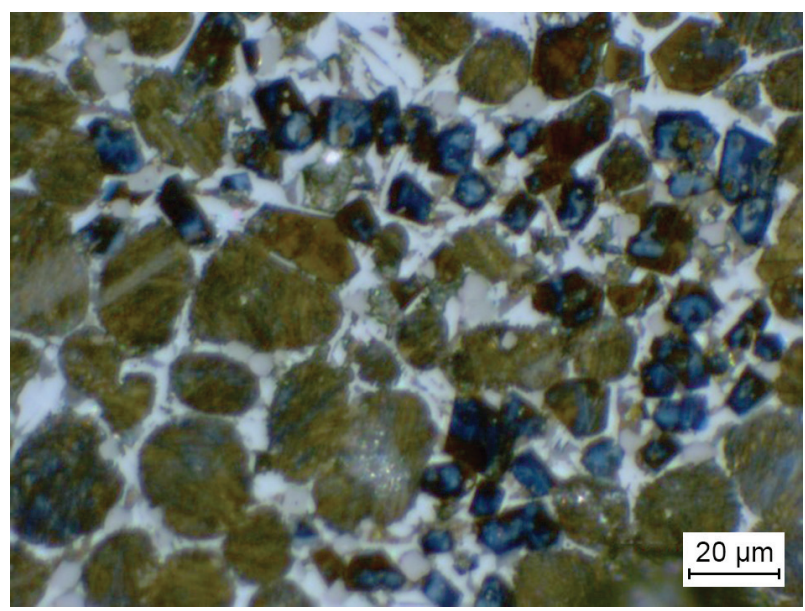

d) $\mathrm{C} 7$

Figure 6. Microscopic view of clinker samples.

$\mathrm{C} 5$ and $\mathrm{C} 0$ the size of alite reduced significantly, and appeared small $\mathrm{MgO}$ grains in $\mathrm{C} 5$. Comparing with $\mathrm{C} 7$ and $\mathrm{C} 0$ petrographic photos, the size of alite and belite were significantly reduced and the size range of alite was $5 \sim 18 \mu \mathrm{m}$, but the number of alite significantly increased in C7. In addition, the boundary of two minerals crystal became roughly, which may be due to dope $\mathrm{MgO}$ made the crystal deteriorated, and therefore reduced the crystal size. All in all, $\mathrm{MgO}$ made the size of alite and belite in cement clinker smaller, which was beneficial to cement hydration.

\section{Compressive strength}

Compressive strength of samples doped with $\mathrm{MgO}, \mathrm{Na}_{2} \mathrm{O}$ and $\mathrm{K}_{2} \mathrm{O}$ were showed in Figure 7. Table 3 gave the strength increase rate of samples doped with $\mathrm{MgO}$. From the table it showed that when hydration $1 \mathrm{~d}$, the compressive strength of cement with $\mathrm{MgO}$ had decreased. At the time of hydration $3 \mathrm{~d}, \mathrm{MgO}$-doped samples compressive strength of cement had increased, except 5.0 wt. $\% \mathrm{MgO}$ content, and $\mathrm{MgO}$ contented with 3.0 wt. $\%, 7.0$ wt. $\%$ and 9.0 wt. $\%$ intensity growth was relatively high, respectively $25 \%, 26 \%$ and $27 \%$. With the extension of hydration age, the intensity of the reference sample increased slowly and its $28 \mathrm{~d}$ strength only 75.8 MPa. Meanwhile, when $\mathrm{MgO}$ content was $3.0 \mathrm{wt}$. $\%$ and $7.0 \mathrm{wt}$. $\%$, the late strength of the sample was relatively high, and the $28 \mathrm{~d}$ intensity of $9.0 \mathrm{wt} \%$ $\mathrm{MgO}$ cement was slightly lower than that of $3.0 \mathrm{wt}$. \% and 7.0 wt. \% $\mathrm{MgO}$. It thus can conclude that $\mathrm{MgO}$ to promote the development of cement strength of the best dope were 3.0 wt. $\%$ and 7.0 wt. $\%$.

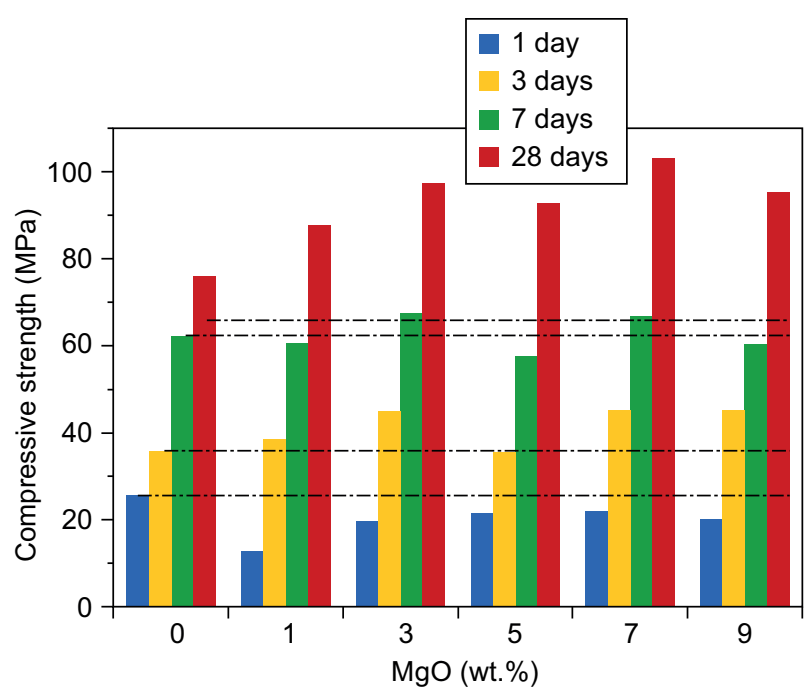

Figure 7. Compressive strengths of cement pastes.

Table 3. Strength increase rate of $\mathrm{MgO}$-doped samples relative to the reference sample $(\mathrm{C} 0)$.

\begin{tabular}{ccccc}
\hline $\begin{array}{c}\text { Sample } \\
\text { label }\end{array}$ & \multicolumn{4}{c}{ Strength improvement rate (versus C0, \%) } \\
\cline { 2 - 5 } & $1 \mathrm{~d}$ & $3 \mathrm{~d}$ & $7 \mathrm{~d}$ & $28 \mathrm{~d}$ \\
\hline C1 & -50 & 8 & -3 & 16 \\
C3 & -23 & 25 & 8 & 28 \\
C5 & -15 & -0.7 & -7 & 22 \\
C7 & -14 & 26 & 7 & 36 \\
C9 & -20 & 27 & -3 & 26 \\
\hline
\end{tabular}

\section{XRD patterns of hydration products}

The unhydrated silicates and hydration products of $\mathrm{CH}$ and ettringite were examined by X-ray diffraction showed in Figure 8. Although the intensity of the diffraction peak was not linearly proportional to the content of crystalline phase, some important information can be obtained from the comparisons of the relative intensity and changes of the intensity with the prolongation of hydration ages. As showed in Figure 8, at 3 days diffraction peaks of $\mathrm{C}_{2.75} \mathrm{~B}_{1.25} \mathrm{~A}_{3} \$$ disappeared, indicating $\mathrm{C}_{2.75} \mathrm{~B}_{1.25} \mathrm{~A}_{3} \$$ been fully hydrated. What's more, $\mathrm{Ca}(\mathrm{OH})_{2}$ and ettringite diffraction peaks appeared more obvious, but C-S-H diffraction peak was relatively weak. 
The intensity of unhydrated $\mathrm{C}_{3} \mathrm{~S}$ and $\mathrm{C}_{2} \mathrm{~S}$ diffraction peak were still high. In addition, it can be seen that in $\mathrm{C} 7$ and C9 samples, $\mathrm{Ca}(\mathrm{OH})_{2}$ diffraction peak $\left(2 \theta=18.0^{\circ}\right)$ was significantly enhanced, at the same time, the variation in peak of ettringite at $9.0^{\circ}$ reflected the same results, indicating that $\mathrm{C} 7$ and $\mathrm{C} 9$ in the $3 \mathrm{~d}$ hydration degree was higher, which was consistent with the results of compressive strength.

At 28 days, the hydration products ettringite, $\mathrm{Ca}(\mathrm{OH})_{2}$ and $\mathrm{C}-\mathrm{S}-\mathrm{H}$ diffraction peaks significantly enhanced, while unhydrated silicates $\left(\mathrm{C}_{3} \mathrm{~S}\right.$ and $\left.\mathrm{C}_{2} \mathrm{~S}\right)$ diffraction peaks decreased significantly and $\mathrm{C}_{3} \mathrm{~S}$ diffraction peak declined more obvious. From this phenomenon it can be conclude that the hydration of $28 \mathrm{~d}$ was significantly higher than $3 \mathrm{~d}$, and therefore the mechanical properties improved.

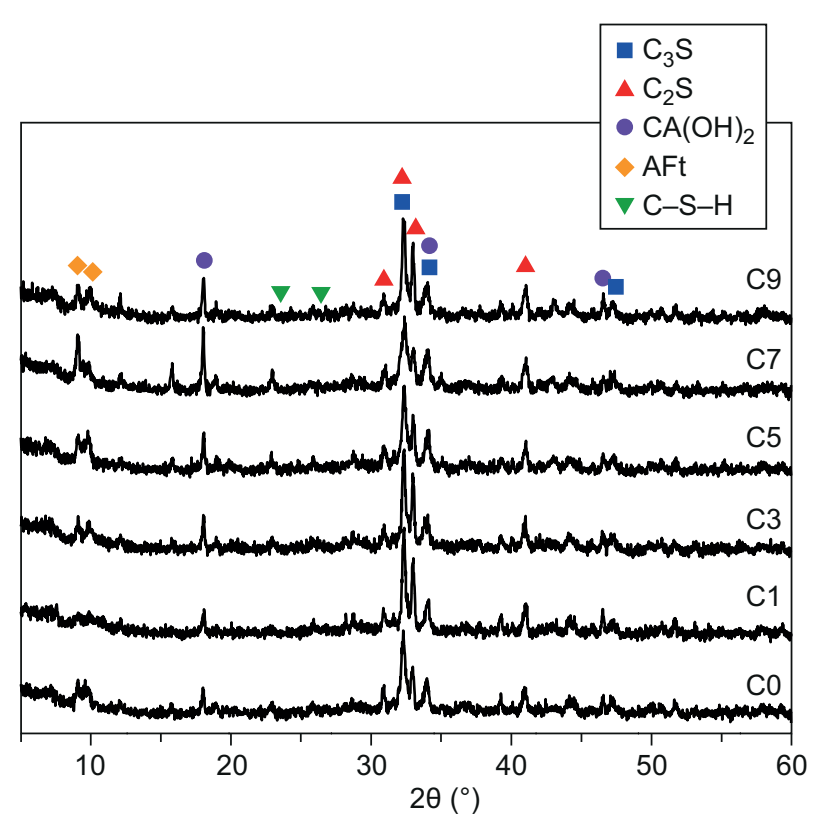

a) 3 days
To reflect the effect of $\mathrm{MgO}$ on the hydration of cement in detail, the heat liberation of hydration of $\mathrm{C} 0, \mathrm{C} 1$ and $\mathrm{C} 7$ during $140 \mathrm{~h}$ were further measured as shown in Figure 9. Figure 9a and Figure 9b respectively displayed the rate of hydration heat release and the cumulative heat release. It can be seen from the Figure 9, within a few hours, there was a strong exothermic peak. The reason why was that $\mathrm{C}_{3} \mathrm{~A}$ and $\mathrm{C}_{2.75} \mathrm{~B}_{1.25} \mathrm{~A}_{3}$ hydrate to produce ettringite and barium-containing ettringite in pre-induced period (ettringite formation period). With the hydration reaction, the hydration product gradually increased, and form a coating in clinker mineral surface, so that the hydration rate slow down, that means the beginning of the induction period. From Figure 9 we knew that induction period $\mathrm{C} 1$ and $\mathrm{C} 0$ samples were

Figure 8. XRD patterns of studied pastes hydrated at the curing ages.

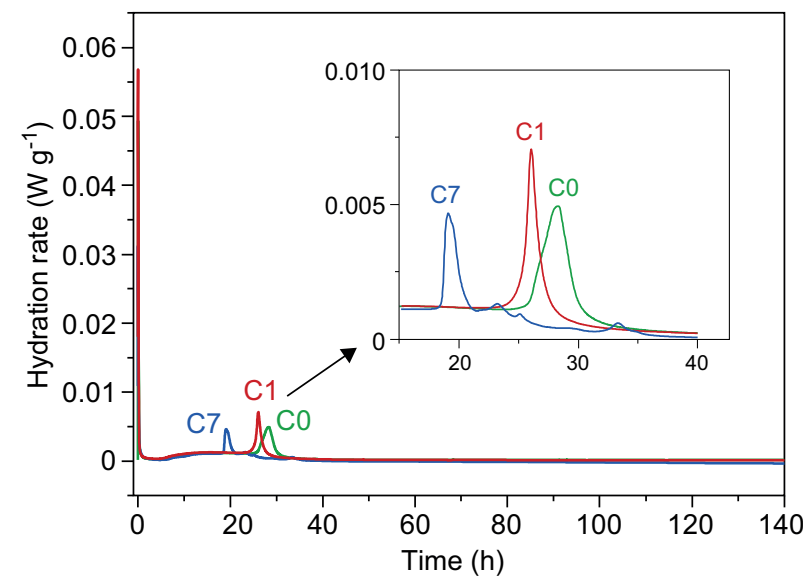

a) Hydration rate curve

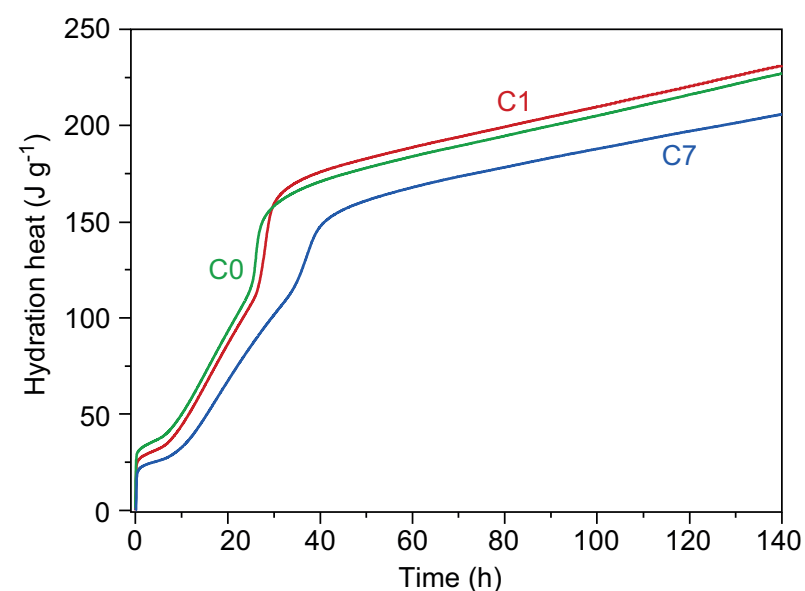

b) Hydration heat release curve

Figure 9. Calorimetic heat flow and heat curves for the studied samples. 
similar, while the maximum rate of hydration $\mathrm{C} 1$ was larger than $\mathrm{C} 0$, and the induction period of $\mathrm{C} 7$ sample was minimal. This showed that under alkaline conditions, $\mathrm{MgO}$ can promote the hydration of cement and when $\mathrm{MgO}$ content was high, the hydration effect was obvious. This result was consistent with the compressive strength results.

\section{Microstructures of hydration samples}

Figure 10 displayed the SEM and EDS photographs of the fracture surface of hardened pastes at 3 days. As showed in Figure 10, in C0 hydration sample, the main hydration products after 3 days were short rod-shaped ettringite and the cotton-shaped structure of $\mathrm{C}-\mathrm{S}-\mathrm{H}$, but there existed some cracks. There were also exist some of needle bar-like ettringite, but the amount of $\mathrm{C}-\mathrm{S}-\mathrm{H}$ became fewer in $\mathrm{C} 5$ sample. $\mathrm{C}-\mathrm{S}-\mathrm{H}$ was mainly filled in the space occupied by water before and cemented together, so that the structure was dense and the performance of the mechanical properties increased. If the gel material was decreased, the cement strength was affected. As we can see from Figure 10c, the ettringite became longer and thicker compared with $\mathrm{C} 0$ and $\mathrm{C} 5$. In addition, gel intertwined with ettringite, which improved the density of structure and provided the basis for the strength. As we can see from the EDS photograph, the trace elements $\mathrm{Na}, \mathrm{K}$ and $\mathrm{Mg}$ were detected on the hydrated product, which indicating that alkali and $\mathrm{MgO}$ could be dissolved in the hydration product. Above three

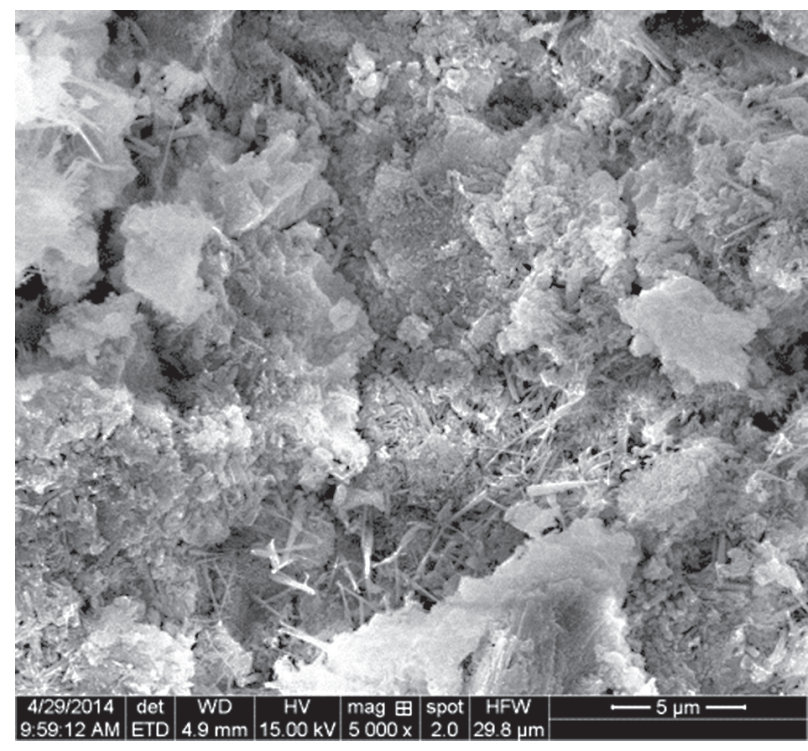

a) $\mathrm{C0}$

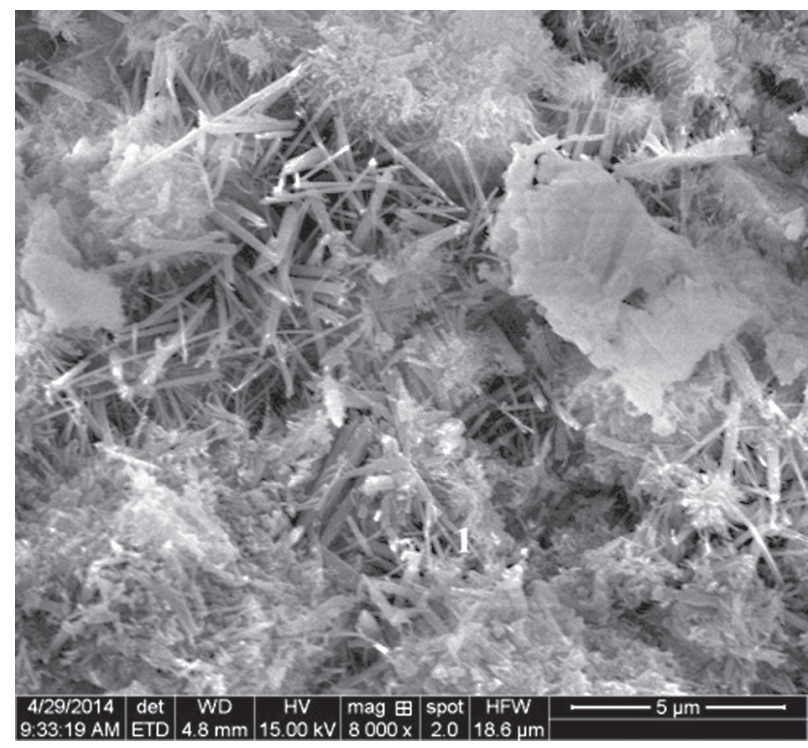

c) $\mathrm{C} 7$

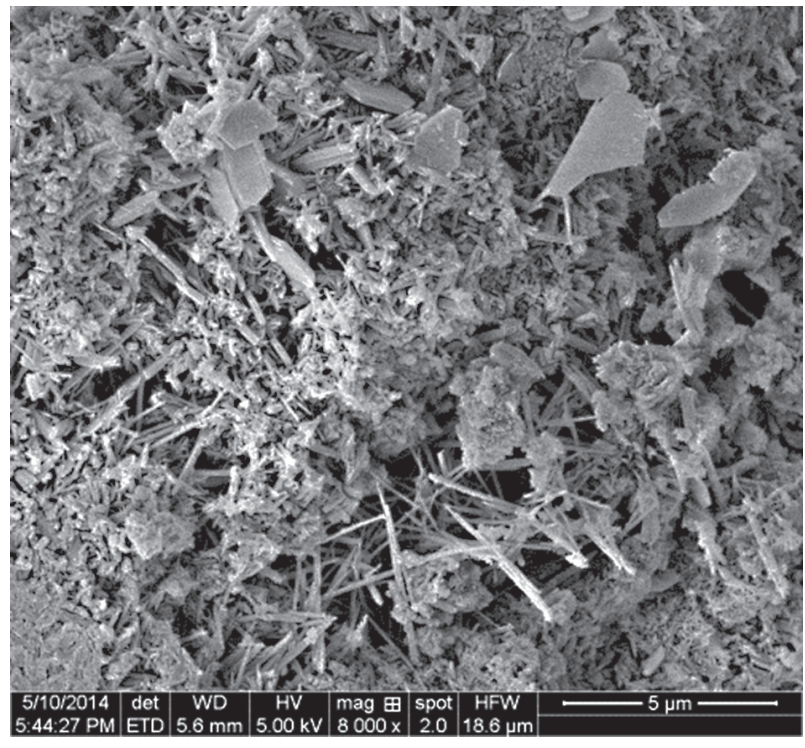

b) $\mathrm{C} 5$

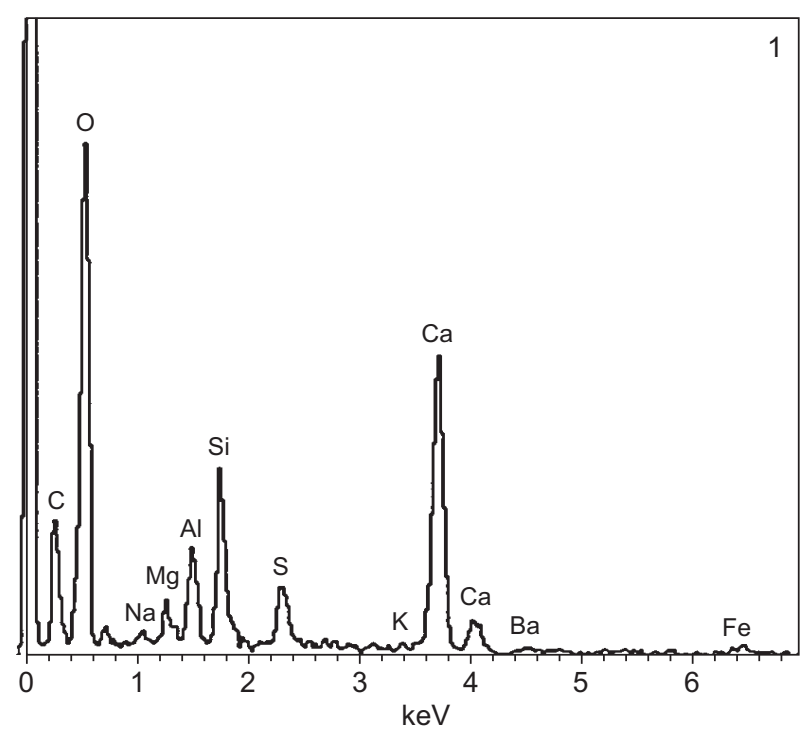

1

Figure 10. SEM-EDS images of hydrated cement pastes at 3 days; a) C0: the reference; b) C5: samples doped with 5 wt. $\% \mathrm{MgO}$;
c) C7: samples doped with 7 wt. $\% \mathrm{MgO}$. 
samples SEM, the hydration degree of C7 sample was larger, and the hydration degree of $\mathrm{C} 5$ is smaller, which were consistent with the XRD analysis of the previous hydration samples.

\section{CONCLUSIONS}

From the present study, the following major conclusions can be drawn:

- Appropriate amount of $\mathrm{MgO}(1 \sim 3$ wt. \%) can improve the burnability of raw materials, promote the formation of $\mathrm{C}_{3} \mathrm{~S}$, and stabilize $\mathrm{M}_{3}-\mathrm{C}_{3} \mathrm{~S}$ and $\mathrm{R}-\mathrm{C}_{3} \mathrm{~S}$. In addition, 7 wt. $\% \mathrm{MgO}$ also favors the formation of $\mathrm{C}_{3} \mathrm{~S}$ and it makes the amount of $\mathrm{C}_{3} \mathrm{~S}$ to the maximum, reaching $38.79 \%$.

- $\mathrm{MgO}$ favors the formation of $\beta-\mathrm{C}_{2} \mathrm{~S}$. Excessive $\mathrm{MgO}$ (>7 wt. \%) decreases the amount of $\mathrm{C}_{2} \mathrm{~S}$.

- $\mathrm{MgO}$ favors the formation of $\mathrm{C}_{4} \mathrm{AF}$, but affects little on the formation of $\mathrm{C}_{2.75} \mathrm{~B}_{1.25} \mathrm{~A}_{3} \$$ and $\mathrm{C}_{3} \mathrm{~A}$. Doped $\mathrm{MgO}$ reduce $\mathrm{C}_{3} \mathrm{~A} / \mathrm{C}_{4} \mathrm{AF}$ ratio and it decreases the viscosity of the liquid.

- $1 \sim 3$ wt. $\% \mathrm{MgO}$ and 7 wt. $\% \mathrm{MgO}$ can increase the compressive strength of the cement, but excessive $\mathrm{MgO}$ will lead to negative effect. The compressive strength of the sample with 7 wt. $\% \mathrm{MgO}$ at 3, 7 and 28 days are 45.1, 66.81 and 103.2 $\mathrm{MPa}$, which increases by $26 \%, 7.3 \%$, and $36.2 \%$ respectively compared to the cement without $\mathrm{MgO}$ dopant.

- $\mathrm{MgO}$ promotes the hydration rate and more $\mathrm{MgO}$ promote the hydration effect obvious. $\mathrm{CH}$ and $\mathrm{AFt}$ obviously increase according to XRD patterns.

- Sample with 7 wt. \% MgO displays a dense and compact microstructure, in which more long acicular ettringite and $\mathrm{C}-\mathrm{S}-\mathrm{H}$ phases are observed.

\section{Acknowledgements}

This research is supported by Natural Science Foundation of China (No.51472109), and Science and Technology Developmentplan of Shandong Province (No.2014GZX208001). Meanwhile, this work is supported by Program for Scientific Research Innovation Team in Colleges and Universities of Shandong Province.

\section{REFERENCES}

1. Arjunan P., Silsbee M. R., Roy D. M. (1999): Sulfoaluminate-belite cement from low-calcium fly ash and sulfur-rich and other industrial by-products. Cement and Concrete Research, 29(8), 1305-1311. doi: 10.1016/S00088846(99)00072-1

2. Puertas F., García-Díaz I., Barba A., Gazulla M. F., Palacios M., Gómez M. P., Martínez-Ramírez S. (2008): Ceramic wastes as alternative raw materials for Portland cement clinker production. Cement and Concrete Composites, 30(9), 798-805. doi: 10.1016/j.cemconcomp.2008.06.003

3. Gartner E. (2004): Industrially interesting approaches to "low- $\mathrm{CO}_{2}$ " cements. Cement and Concrete Research, 34(9), 1489-1498. doi: 10.1016/j.cemconres.2004.01.021

4. De la Torre A. G., Aranda M. A. G., De Aza A. H., Pena P., De Aza S. (2005): Belite portland clinkers. Synthesis and mineralogical analysis. Bol. Soc. Esp. Ceram. Vidrio, 44(3), 185-191.

5. Morsli K., Ángeles G., Zahir M., Aranda M. A. (2007): Mineralogical phase analysis of alkali and sulfate bearing belite rich laboratory clinkers. Cement and Concrete Research, 37(5), 639-646. doi: 10.1016/j.cemconres.2007. 01.012

6. Morsli K., De La Torre Á. G., Stöber S., Cuberos A. J., Zahir M., Aranda M. A. (2007): Quantitative Phase Analysis of Laboratory-Active Belite Clinkers by Synchrotron Powder Diffraction. Journal of the American Ceramic Society, 90(10), 3205-3212. doi: 10.1111/j.1551-2916.2007.01870.x

7. Iacobescu R. I., Koumpouri D., Pontikes, Y., Angelopoulos G. N. (2013): Hydraulic and leaching behaviour of belite cements produced with electric arc furnace steel slag as raw material. Ceramics-Silikaty, 57(2), 126-132.

8. Chatterjee A. K. (1996): High belite cements-present status and future technological options: part I. Cement and Concrete Research, 26(8), 1213-1225. doi: 10.1016/00088846(96)00099-3

9. Kacimi L., Simon-Masseron A., Salem S., Ghomari A., Derriche Z. (2009): Synthesis of belite cement clinker of high hydraulic reactivity. Cement and Concrete Research, 39(7), 559-565. doi: 10.1016/j.cemconres.2009.02.004

10. Kim Y. M., Hong S. H. (2004): Influence of minor ions on the stability and hydration rates of $\beta$-dicalcium silicate. Journal of the American Ceramic Society, 87(5), 900-905. doi: 10.1111/j.1551-2916.2004.00900.x

11. Ichikawa M., Ikeda S., Komukai Y. (1994): Effect of cooling rate and $\mathrm{Na}_{2} \mathrm{O}$ content on the character of the interstitial materials in Portland cement clinker. Cement and Concrete Research, 24(6), 1092-1096. doi: 10.1016/00088846(94)90033-7

12. Qiu G.H. (2012). Experimental research on utilization of coal gangue, tailings as clay mixed with low-grade limestone for cement clinker calcinations, M.S. Thesis, Zhejiang University.

13. Li X., Huang H., Xu J., Ma S., Shen X. (2012): Statistical research on phase formation and modification of alite polymorphs in cement clinker with $\mathrm{SO}_{3}$ and $\mathrm{MgO}$. Construction and Building Materials, 37, 548-555. doi: 10.1016/j.conbuildmat.2012.07.099

14. Taylor H.F.W. (1997). Cement chemistry. Thomas Telford, London.

15. Altun I. A. (1999): Effect of $\mathrm{CaF}_{2}$ and $\mathrm{MgO}$ on sintering of cement clinker. Cement and Concrete Research, 29(11), 1847-1850. doi: 10.1016/S0008-8846(99)00151-9

16. Stephan D., Dikoundou S. N., Raudaschl-Sieber G. (2008): Hydration characteristics and hydration products of tricalcium silicate doped with a combination of $\mathrm{MgO}, \mathrm{Al}_{2} \mathrm{O}_{3}$ and $\mathrm{Fe}_{2} \mathrm{O}_{3}$. Thermochimica Acta, 472(1), 64-73. doi: 10.1016/j.tca.2008.03.013

17. Rehsi, S. S. (1983). Magnesium oxide in portland cement. In Advances in Cement Technology. Pergamon Press Ltd. pp. 467-483. doi: 10.1016/B978-0-08-028670-9.50019-3. 
18. De la Torre A.G., De Vera R.N., Cuberos A.J.M., Aranda, M. A. (2008): Crystal structure of low magnesium-content alite: Application to Rietveld quantitative phase analysis. Cement and Concrete Research, 38(11), 1261-1269. doi: 10.1016/j.cemconres.2008.06.005

19. Gies A., Knofel D. (1986): Influence of alkalies on the composition of belite-rich cement clinkers and the technological properties of the resulting cements. Cement and Concrete Research, 16(3): 411-422. doi: 10.1016/00088846(86)90117-1

20. Rietveld H. (1969): A profile refinement method for nuclear and magnetic structures. Journal of Applied Crystallography, 2(2), 65-71. doi: 10.1107/S0021889869006558

21. De la Torre A. G., Aranda M. G. (2003). Accuracy in Rietveld quantitative phase analysis of Portland cements. Journal of Applied Crystallography, 36(5), 1169-1176. doi: 10.1107/S002188980301375X

22. Cheary R. W., Coelho A. A., Cline J. P. (2004): Fundamental parameters line profile fitting in laboratory diffractometers. Journal of Research of the National Institute of Standards and Technology, 109(1), 1-25. doi: 10.6028/jres.002

23. Coelho A. A. (2000): Whole-profile structure solution from powder diffraction data using simulated annealing. Journal of Applied Crystallography, 33(3), 899-908. doi: 10.1107/ S002188980000248X

24. Maki I. (1986). Relationship of processing parameters to clinker properties; influence of minor components, in: Proceedings of the 8th International Congress of Cement Chemistry. Rio de Janeiro, Brazil, 1986. pp. 34-37.

25. Liu X., Li Y. (2005). Effect of $\mathrm{MgO}$ on the composition and properties of alite-sulphoaluminate cement. Cement and Concrete Research, 35(9), 1685-1687. doi: 10.1016/j. cemconres.2004.08.008

26. Li X., Xu W., Wang S., Tang M., Shen X. (2014): Effect of $\mathrm{SO}_{3}$ and $\mathrm{MgO}$ on Portland cement clinker: Formation of clinker phases and alite polymorphism. Construction and Building Materials, 58, 182-192. doi: 10.1016/j. conbuildmat.2014.02.029

27. Cheary R.W., Coelho A.A. (1992): A fundamental parameters approach to X-ray line profile fitting. Journal of Applied Crystallography, 25(E4), 109-121. doi:10.1107/ S0021889891010804

28. Staněk T., Sulovský P. (2002): The influence of the alite polymorphism on the strength of the Portland cement. Cement and Concrete Research, 32(7), 1169-1175. doi: 10.1016/S0008-8846(02)00756-1

29. Cuberos A.J.M., De la Torre A.G., Martín-Sedeño M.C., Moreno R.L., Merlini M.,Ordonez L.M., Aranda M.A.G. (2009): Phase development in conventional and active belite cement pastes by Rietveld analysis and chemical constraints. Cement and Concrete Research, 39(10), 833842. doi: 10.1016/j.cemconres.2009.06.017

30. Wang Q.Q., Li F., Shen X.D., Shi W.J., Li X.R., Guo Y.H., Xiong S.J., Zhuang Q. (2014): Relation between reactivity and electronic structure for $\alpha^{\prime} \mathrm{L}$-, $\beta$-and $\gamma$-dicalcium silicate: A first-principles study. Cement and Concrete Research, 57, 28-32. doi: 10.1016/j.cemconres.2013.12.004

31 . Bensted, J. (1978): $\delta$-dicalcium silicate and its hydraulicity. Cement and Concrete Research, 8(1), 73-76. doi: 10.1016/ 0008-8846(78)90059-5

32. Campbell D.H. (1999). Microscopical Examination and Interpretation of Portland Cement and Clinker, $2^{\text {nd }}$ ed., Portland Cement Association, USA, pp.16-18, 68-72. 